\title{
Quality Measures that Matter
}

\author{
Regina F. Bento and Lourdes F. White \\ Merrick School of Business, University of Baltimore, \\ Baltimore, Maryland, USA
}

\author{
rbento@ubalt.edu; Iwhite@ubalt.edu
}

\begin{abstract}
The increasing number of courses offered online by universities and other institutions of higher education has created an equally increasing need for reliable standards to evaluate the quality of the course design. This paper reviews the Quality Matters (QM) Rubric, which is arguably becoming the national standard for evaluation of the quality of online courses in the United States. To illustrate the use of a QM Rubric, the 40 standards (including essential, very important and important standards) are applied to the case of a graduate accounting course offered online by a state university in the Mid-Atlantic area of the United States. The ease of use and difficulties associated with applying the QM rubric are discussed, and potential benefits to faculty and students from the implementation of QM standards are highlighted. Based on this case study, from the faculty viewpoint, the main potential benefit from QM implementation is the alignment of learning objectives with the selection of assessment instruments and instructional materials. From the student viewpoint, the main potential benefit is the increased clarity in the presentation of faculty expectations and the improved access to course components.
\end{abstract}

Keywords: quality standards, online education, Quality Matters Rubric

\section{Introduction}

According to periodic surveys by the National Center for Education Statistics (2008), the number of degree-granting postsecondary institutions in the United States that offer distance education courses has increased from $56 \%$ in 2001 to $66 \%$ in 2007 . Most notably, by $2007,77 \%$ of the enrollments in distance education courses were reported in online courses, corresponding to an estimated 9.4 million US students enrolled in courses delivered entirely online. Such growth in online education has spurred concern over the quality of the learning experience.

Over the past decade, there has been a significant effort to develop research-based criteria for rigorous evaluation of online courses and academic programs. This effort has resulted in an increasing emphasis on assessment, as manifested in the standards put forth by national and international accrediting agencies (see, for example, the assurance of learning standards established by the As-

Material published as part of this publication, either on-line or in print, is copyrighted by the Informing Science Institute. Permission to make digital or paper copy of part or all of these works for personal or classroom use is granted without fee provided that the copies are not made or distributed for profit or commercial advantage AND that copies 1) bear this notice in full and 2) give the full citation on the first page. It is permissible to abstract these works so long as credit is given. To copy in all other cases or to republish or to post on a server or to redistribute to lists requires specific permission and payment of a fee. Contact 0HPublisher@InformingScience.org to request redistribution permission. sociation to Advance Collegiate Schools of Business or AACSB International described in AACSB, 2009). Coinciding with this emphasis on assessment, the growth in online learning has compelled institutions in higher education to define what quality means for an online course.

Drawing from a literature review of 160 articles and twelve books, Chaney (2006) identified 14 quality indicators of 
distance education, involving aspects of the student-teacher relationship (e.g., frequency of feedback, respect for diverse ways of learning), institutional support (such as faculty support services, program evaluation and assessment, institutional mission), and technology (e.g., appropriate tools and media, reliability of the course technology). Other studies on the quality of distance education have focused on the students' perspective (Chaney, Eddy, Dorman, Glessner, Green \& LaraAlecio, 2007), attempting to measure students' attitudes, opinions, and perceptions. Still others were motivated by a pragmatic need to develop reliable course evaluation instruments (Achtemeier, Morris \& Finnegan, 2003).

In 2003, a consortium of colleges in Maryland named Maryland Online obtained a three-year grant from the Fund for the Improvement of Post-Secondary Education (FIPSE) of the United States Department of Education to build a program for faculty development and continuous improvement in online education, with the specific goal of developing a quality assurance process leading to the quality certification of online courses. Thus the Quality Matters (QM) Rubric was developed, and, after the FIPSE grant expired in 2006, Quality Matters became a self-supporting organization offering course reviews for QM certification and faculty training programs.

This paper aims at illustrating the use of the QM rubric in the case of a graduate online course. The next section reviews the main characteristics of the QM certification process and standards, and summarizes the theoretical underpinnings of the QM standards. The third section of the paper applies the 40 QM standards to an online accounting course required for students in the Masters of Business Administration program of a state university in the US, followed by a fourth section on the ease of use and difficulties encountered when applying the QM standards to this particular course. The conclusion section summarizes the main benefits gained from the process of applying for QM certification, and suggests topics for further research in the area of measuring quality of online courses.

\section{QM Rubric}

The QM certification process was developed based on four principles:

- Centered: the QM rubric draws from research findings and is updated periodically according to developments in the instructional design literature.

- Collaborative: the peer review team (composed of three members, one of which is an expert in the subject matter) and the course developer evaluate the course based on evidence from the course website, instead of opinions of individual reviewers.

- Collegial: the course developer and the peer review team interact in a collegial, not a judgmental way.

- Continuous improvement: as part of a continuous improvement process, course developers are expected to make changes in the course design until all QM standards are met.

The reviewers take the student viewpoint, and investigate if the course design, course components and instructions to students meet the standards set in the QM rubric; there is no direct evaluation of the course academic content or the way in which the instructor delivers the course while interacting with students.

Based on an extensive review of the online education literature and of best practices, $40 \mathrm{QM}$ standards were developed and organized around eight dimensions:

1. Course Overview and Introduction

2. Learning Objectives

3. Assessment and Measurement 


\section{Resources and Materials}

\section{Learner Engagement}

6. Course Technology

\section{Learner Support}

\section{Accessibility}

Out of the 40 standards, 17 are classified as essential, and courses are rated on a 3-point scale according to how well they meet those standards; 11 standards are classified as very important and rated on a 2-point scale; and 12 other standards are classified as important and rated on a 1-point scale. In order to be QM certified, a course must meet all essential standards and earn a minimum of 72 out of a maximum of 85 points. A more detailed discussion of the 40 standards appears in the next section.

The standards included in the first dimension, Course Overview and Introduction, assess if the course design is clear to students from the very beginning of the course, as students benefit from seeing all course components built into one consistent design, instead of having those elements added as the course progresses (Welker \& Berardino, 2005).

Learning objectives constitute the second dimension, but also influence other dimensions such as assessment and measurement, resources and materials, learner engagement and course technology, through an alignment process, whereby all elements of the course are linked to and support the achievement of the learning objectives. Except for the standards related to course review and introduction, all other essential standards have a direct or indirect relationship to the attainment of the learning objectives. This is grounded in a well-established literature on the role of learning objectives, starting with the seminal work of Bloom (1956) and continuing over the last five decades, including recent work by Stewart, Hong, and Strudler (2004) and Koszalka and Ganesan (2004).

The assessment and measurement dimension is intended to insure that student learning is measured along the course using instruments consistent with the learning objectives, and that students are provided with sufficient feedback to stimulate participation and active learning. Especially in the online environment, frequent and effective assessment and measurement is strongly associated with student satisfaction and performance (Thurmond, Wambach, Connors, \& Frey, 2002; Youngblood, Trede, \& DeCorpo, 2001).

Resources and materials are evaluated in the fourth dimension not in terms of their specific academic content, but in terms of their suitability for the achievement of the learning objectives and the reliability of their sources (whether produced by the instructor or by textbook publishers). This is consistent with findings in the literature that systematically place learner-content interaction as one of the critical elements in course design (Garrison, Anderson, \& Archer, 2001; Rourke, Anderson, Garrison \& Archer, 2001).

Learner engagement, the fifth dimension, includes standards aimed at promoting the various forms of interaction. Traditionally, three types of interaction - student/teacher; student/student; and student/content were emphasized in the literature (Moore, 2007), but other forms of interaction have become possible in online courses (Roblyer \& Wiencke, 2003). All types of interaction share one purpose: to motivate learners to commit to the learning process. Substantial empirical research supports indirect relationships between student engagement and perceived learning and satisfaction (Swan, 2003).

The sixth dimension of course technology has an obvious role in the delivery of quality online courses. However, rather than a focus on whether a course uses the latest technology, the QM standards focus on whether the tools and media selected for the course are appropriate for the 
achievement of the learning objectives. While it is clear that innovative technologies help engage students with certain demographic characteristics such as those from generation $\mathrm{X}$ and millenial students, the most important purpose of the technology is for stimulating learning (Moore, 2007).

Finally, the seventh and eighth dimensions relate to meeting the needs of different kinds of learners. Learner support standards examine the extent to which the course informs students about institutional resources available (such as technical support, academic tutoring, and counseling services) and are relatively easy to meet, but can significantly impact the quality of the learning experience (Chaney et al., 2007). Accessibility standards, besides meeting the legal requirements for reasonable accommodations established by the Americans with Disabilities Act, increase the flexibility for all learners and help students realize some of the benefits that online education promised to offer (Kinash, Crichton, \& Kim-Rupnow, 2004).

\section{Applying QM Standards}

The authors collaborated on the development of the course Accounting for Managerial Decisions to be delivered online as part of the core curriculum for the Masters in Business Administration program at a state university in the mid-Atlantic area of the United States. The course was delivered using WebTycho as the course platform, and required no special knowledge of technology beyond mastery of tools in the Microsoft Office Suite.

The course introduced students to some technical tools of accounting, such as the cost-volumeprofit model, activity-based costing, transfer pricing and residual income calculations, as well as the role of accounting in business decisions. To assess student understanding of the technical tools, weekly quizzes were developed for various chapters in the textbook; to illustrate how managers use accounting in business decisions, students worked in groups to discuss complex, reallife case studies. Students also were assigned practice problems from the textbook and solutions were provided in the course website for self-checking.

The second author was charged with preparing the course for Quality Matters Review. As a first step in the process of applying for a course review, she performed a self-evaluation of how the course design scored according to the QM Rubric. Table 1 illustrates the outcomes of this self-assessment.

Table 1: Applying the Quality Matters Rubric to a Graduate Accounting Course

\begin{tabular}{|l|l|l|l|l|}
\hline $\begin{array}{l}\text { STAN- } \\
\text { DARD } \\
\#\end{array}$ & \multicolumn{1}{|c|}{$\begin{array}{c}\text { FROM THE QM RUBRIC } \\
\text { 1. }\end{array}$} & $\begin{array}{l}\text { RELATIVE } \\
\text { VALUE }\end{array}$ & $\begin{array}{c}\text { MAXI- } \\
\text { MUM } \\
\text { POINTS }\end{array}$ & \multicolumn{1}{|c|}{ SELF-EVALUATION } \\
\hline 1.1 & $\begin{array}{l}\text { Course Review and Introduction } \\
\begin{array}{l}\text { Instructions make clear how to get } \\
\text { started and where to find various course } \\
\text { components. }\end{array}\end{array}$ & Essential & 3 & $\begin{array}{l}\text { 2- instructions available on } \\
\text { the syllabus but not imme- } \\
\text { diately noticeable }\end{array}$ \\
\hline 1.2 & $\begin{array}{l}\text { A statement introduces the student to the } \\
\text { purpose of the course and to its compo- } \\
\text { nents. }\end{array}$ & Essential & 3 & 3 - included on the syllabus \\
\hline 1.3 & $\begin{array}{l}\text { Etiquette expectations for online discus- } \\
\text { sions, email, and other forms of commu- } \\
\text { nication are stated clearly. }\end{array}$ & Important & 1 & 1 - included on the syllabus \\
\hline 1.4 & $\begin{array}{l}\text { The self-introduction by the instructor is } \\
\text { appropriate and available online. }\end{array}$ & Important & 1 & $\begin{array}{l}1 \text { - included in the discus- } \\
\text { sion area }\end{array}$ \\
\hline 1.5 & $\begin{array}{l}\text { Students are asked to introduce them- } \\
\text { selves to the class }\end{array}$ & Important & 1 & $\begin{array}{l}1 \text { - included in the discus- } \\
\text { sion area }\end{array}$ \\
\hline
\end{tabular}




\begin{tabular}{|c|c|c|c|c|}
\hline $\begin{array}{l}\text { STAN- } \\
\text { DARD } \\
\quad \#\end{array}$ & $\begin{array}{c}\text { DESCRIPTION } \\
\text { FROM THE QM RUBRIC }\end{array}$ & $\begin{array}{l}\text { RELATIVE } \\
\text { VALUE }\end{array}$ & $\begin{array}{l}\text { MAXI- } \\
\text { MUM } \\
\text { POINTS }\end{array}$ & SELF-EVALUATION \\
\hline 1.6 & $\begin{array}{l}\text { Minimum student preparation, and, if } \\
\text { applicable, prerequisite knowledge are } \\
\text { clearly stated. }\end{array}$ & Important & 1 & 1- included on the syllabus \\
\hline 1.7 & $\begin{array}{l}\text { Minimum technical skills expected of } \\
\text { student are clearly stated. }\end{array}$ & Important & 1 & 1- included on the syllabus \\
\hline 2. & Learning Objectives (L.Os) & & & \\
\hline 2.1 & $\begin{array}{l}\text { The course learning objectives describe } \\
\text { outcomes that are clearly measurable. }\end{array}$ & Essential & 3 & 3 - included on the syllabus \\
\hline 2.2 & $\begin{array}{l}\text { The module/unit learning objectives de- } \\
\text { scribe outcomes that are measurable and } \\
\text { consistent with the course-level L.Os. }\end{array}$ & Essential & 3 & $\begin{array}{l}0 \text { - there were no mod- } \\
\text { ule/unit L.Os. }\end{array}$ \\
\hline 2.3 & $\begin{array}{l}\text { All learning objectives are stated clearly } \\
\text { and written from the students' perspec- } \\
\text { tive. }\end{array}$ & Essential & 3 & 3 - included on the syllabus \\
\hline 2.4 & $\begin{array}{l}\text { Instructions to students on how to meet } \\
\text { the learning objectives are adequate and } \\
\text { stated clearly. }\end{array}$ & Essential & 3 & $\begin{array}{l}0 \text { - there were no mod- } \\
\text { ule/unit L.Os. }\end{array}$ \\
\hline 2.5 & $\begin{array}{l}\text { The learning objectives are appropriately } \\
\text { designed for the level of the course. }\end{array}$ & $\begin{array}{l}\text { Very impor- } \\
\text { tant }\end{array}$ & 2 & 2 - included on the syllabus \\
\hline 3. & Assessment and Measurement & & & \\
\hline 3.1 & $\begin{array}{l}\text { The types of assessments selected meas- } \\
\text { ure the stated L.Os. and are consistent } \\
\text { with course activities and resources. }\end{array}$ & $\begin{array}{l}\text { Very impor- } \\
\text { tant }\end{array}$ & 2 & $\begin{array}{l}1 \text { - lacking a clear map link- } \\
\text { ing L.Os with assessments }\end{array}$ \\
\hline 3.2 & $\begin{array}{l}\text { The course grading policy is stated clear- } \\
\text { ly. }\end{array}$ & Essential & 3 & $\begin{array}{l}2 \text { - included on the syllabus } \\
\text { but students still unclear }\end{array}$ \\
\hline 3.3 & $\begin{array}{l}\text { Specific and descriptive criteria are pro- } \\
\text { vided for the evaluation of students' work } \\
\text { and participation. }\end{array}$ & Essential & 3 & $\begin{array}{l}2 \text { - participation criteria not } \\
\text { specific enough }\end{array}$ \\
\hline 3.4 & $\begin{array}{l}\text { The assessment instruments selected are } \\
\text { sequenced, varied, and appropriate to the } \\
\text { content being assessed. }\end{array}$ & $\begin{array}{l}\text { Very impor- } \\
\text { tant }\end{array}$ & 2 & 2 - included on the syllabus \\
\hline 3.5 & $\begin{array}{l}\text { "Self-check" or practice assignments are } \\
\text { provided, with timely feedback to stu- } \\
\text { dents }\end{array}$ & $\begin{array}{l}\text { Very impor- } \\
\text { tant }\end{array}$ & 2 & $\begin{array}{l}2 \text { - weekly quizzes designed } \\
\text { to test comprehension of } \\
\text { chapter concepts }\end{array}$ \\
\hline 4. & Resources and Materials & & & \\
\hline 4.1 & $\begin{array}{l}\text { The instructional materials contribute to } \\
\text { the achievement of the stated course and } \\
\text { module/unit L. Os. }\end{array}$ & Essential & 3 & $\begin{array}{l}2 \text { - lacking a clear map link- } \\
\text { ing L.Os with instructional } \\
\text { materials }\end{array}$ \\
\hline 4.2 & $\begin{array}{l}\text { The relationship between the instruc- } \\
\text { tional materials and the learning activi- } \\
\text { ties is clearly explained to the student. }\end{array}$ & Essential & 3 & $\begin{array}{l}2 \text { - lacking a clear map link- } \\
\text { ing L.Os with instructional } \\
\text { materials }\end{array}$ \\
\hline 4.3 & $\begin{array}{l}\text { The instructional materials have suffi- } \\
\text { cient breadth, depth, and currency for the } \\
\text { student to learn the subject. }\end{array}$ & Essential & 3 & 3 - included on the syllabus \\
\hline 4.4 & $\begin{array}{l}\text { All resources and materials used in the } \\
\text { course are appropriately cited. }\end{array}$ & Important & 1 & 1 - included on the syllabus \\
\hline
\end{tabular}




\begin{tabular}{|c|c|c|c|c|}
\hline $\begin{array}{l}\text { STAN- } \\
\text { DARD } \\
\quad \#\end{array}$ & $\begin{array}{c}\text { DESCRIPTION } \\
\text { FROM THE QM RUBRIC }\end{array}$ & $\begin{array}{l}\text { RELATIVE } \\
\text { VALUE }\end{array}$ & $\begin{array}{l}\text { MAXI- } \\
\text { MUM } \\
\text { POINTS }\end{array}$ & SELF-EVALUATION \\
\hline 5. & Learner Engagement & & & \\
\hline 5.1 & $\begin{array}{l}\text { The learning activities promote the } \\
\text { achievement of the stated L. Os. }\end{array}$ & Essential & 3 & $\begin{array}{l}2 \text { - lacking a clear map link- } \\
\text { ing L.Os with learning ac- } \\
\text { tivities }\end{array}$ \\
\hline 5.2 & $\begin{array}{l}\text { Learning activities foster instructor- } \\
\text { student, content-student, and if appropri- } \\
\text { ate to the course, student-student interac- } \\
\text { tion. }\end{array}$ & Essential & 3 & $\begin{array}{l}3 \text { - included on the syllabus, } \\
\text { explained in the conference } \\
\text { area, reinforced in the class } \\
\text { announcements page. }\end{array}$ \\
\hline 5.3 & $\begin{array}{l}\text { Clear standards are set for instructor re- } \\
\text { sponsiveness and availability. }\end{array}$ & $\begin{array}{l}\text { Very impor- } \\
\text { tant }\end{array}$ & 2 & 2 - included on the syllabus \\
\hline 5.4 & $\begin{array}{l}\text { The requirements for student interaction } \\
\text { are clearly articulated. }\end{array}$ & $\begin{array}{l}\text { Very impor- } \\
\text { tant }\end{array}$ & 2 & $\begin{array}{l}1 \text { - included on the syllabus } \\
\text { but lacking clear rubric }\end{array}$ \\
\hline 6. & Course Technology & & & \\
\hline 6.1 & $\begin{array}{l}\text { The tools and media support the learning } \\
\text { objectives, and are appropriately chosen } \\
\text { to deliver the content of the course. }\end{array}$ & Essential & 3 & $\begin{array}{l}3 \text { - explanations for each } \\
\text { tool are found in areas of the } \\
\text { course website, along with } \\
\text { their support for L.Os. }\end{array}$ \\
\hline 6.2 & $\begin{array}{l}\text { The tools and media support student en- } \\
\text { gagement and guide the student to be- } \\
\text { come an active learner. }\end{array}$ & Essential & 3 & $\begin{array}{l}3 \text { - weekly quizzes, case } \\
\text { discussions, links to web- } \\
\text { sites of interest, help engage } \\
\text { the student in learning proc- } \\
\text { ess }\end{array}$ \\
\hline 6.3 & $\begin{array}{l}\text { Navigation throughout the online com- } \\
\text { ponents of the course is logical, consis- } \\
\text { tent, and efficient. }\end{array}$ & Essential & 3 & $\begin{array}{l}\text { 3- during week } 1 \text { students } \\
\text { practice using each area of } \\
\text { the course website }\end{array}$ \\
\hline 6.4 & $\begin{array}{l}\text { Students have ready access to the tech- } \\
\text { nologies required in the course. }\end{array}$ & $\begin{array}{l}\text { Very impor- } \\
\text { tant }\end{array}$ & 2 & $\begin{array}{l}2 \text { - videos, print materials, } \\
\text { templates are available from } \\
\text { course website or the book- } \\
\text { store. }\end{array}$ \\
\hline 6.5 & $\begin{array}{l}\text { The course components are compatible } \\
\text { with current standards for delivery mod- } \\
\text { es. }\end{array}$ & Important & 1 & $\begin{array}{l}1 \text { - course components up- } \\
\text { dated regularly to take ad- } \\
\text { vantage of appropriate tech- } \\
\text { nologies. }\end{array}$ \\
\hline 6.6 & $\begin{array}{l}\text { Instructions on how to access resources } \\
\text { at a distance are sufficient and easy to } \\
\text { understand. }\end{array}$ & Important & 1 & $\begin{array}{l}1 \text { - instructions on the sylla- } \\
\text { bus and throughout course } \\
\text { website. }\end{array}$ \\
\hline 6.7 & $\begin{array}{l}\text { The course design takes full advantage of } \\
\text { available tools and media. }\end{array}$ & Important & 1 & $\begin{array}{l}1 \text { - use of Real Player, com- } \\
\text { pressed files, and Microsoft } \\
\text { Office tools facilitate stu- } \\
\text { dent use. }\end{array}$ \\
\hline 7. & Learner Support & & & \\
\hline 7.1 & $\begin{array}{l}\text { The course instructions articulate or link } \\
\text { to a clear description of the technical } \\
\text { support offered. }\end{array}$ & $\begin{array}{l}\text { Very impor- } \\
\text { tant }\end{array}$ & 2 & $\begin{array}{l}2 \text { - instructions and links for } \\
\text { technical support included } \\
\text { in the class announcements } \\
\text { page and on the syllabus }\end{array}$ \\
\hline
\end{tabular}




\begin{tabular}{|c|c|c|c|c|}
\hline $\begin{array}{l}\text { STAN- } \\
\text { DARD } \\
\quad \#\end{array}$ & $\begin{array}{c}\text { DESCRIPTION } \\
\text { FROM THE QM RUBRIC }\end{array}$ & $\begin{array}{l}\text { RELATIVE } \\
\text { VALUE }\end{array}$ & $\begin{array}{l}\text { MAXI- } \\
\text { MUM } \\
\text { POINTS }\end{array}$ & SELF-EVALUATION \\
\hline 7.2 & $\begin{array}{l}\text { Course instructions articulate or link to } \\
\text { an explanation of how the institution's } \\
\text { academic support system can assist the } \\
\text { student in effectively using the resources } \\
\text { provided. }\end{array}$ & $\begin{array}{l}\text { Very impor- } \\
\text { tant }\end{array}$ & 2 & $\begin{array}{l}2 \text { - instructions and links for } \\
\text { academic support included } \\
\text { in the class announcements } \\
\text { page and on the syllabus }\end{array}$ \\
\hline 7.3 & $\begin{array}{l}\text { Course instructions articulate or link to } \\
\text { an explanation of how the institution's } \\
\text { student support services can help stu- } \\
\text { dents reach their educational goals. }\end{array}$ & Important & 1 & $\begin{array}{l}1 \text { - instructions and links for } \\
\text { student support included in } \\
\text { the class announcements } \\
\text { page and on the syllabus }\end{array}$ \\
\hline 7.4 & $\begin{array}{l}\text { Course instructions answer basic ques- } \\
\text { tions related to research, writing, tech- } \\
\text { nology, etc., or link to tutorials or other } \\
\text { resources that provide the information. }\end{array}$ & Important & 1 & $\begin{array}{l}1 \text { - instructions and links to } \\
\text { technical tutorials and li- } \\
\text { brary resources available on } \\
\text { the syllabus and on the } \\
\text { course website. }\end{array}$ \\
\hline 8. & Accessibility & & & \\
\hline 8.1 & $\begin{array}{l}\text { The course incorporates ADA standards } \\
\text { and reflects conformance with institu- } \\
\text { tional policy regarding accessibility in } \\
\text { online and hybrid courses. }\end{array}$ & Essential & 3 & $\begin{array}{l}3 \text { - course platform, Web- } \\
\text { Tycho, is ADA-compliant; } \\
\text { course links to University } \\
\text { policy on accessibility. }\end{array}$ \\
\hline 8.2 & $\begin{array}{l}\text { Course pages and course materials pro- } \\
\text { vide equivalent alternatives to auditory } \\
\text { and visual content. }\end{array}$ & $\begin{array}{l}\text { Very impor- } \\
\text { tant }\end{array}$ & 2 & $\begin{array}{l}0 \text { - video lectures had corre- } \\
\text { sponding Powerpoint slides } \\
\text { but no transcripts for hear- } \\
\text { ing-impaired students. }\end{array}$ \\
\hline 8.3 & $\begin{array}{l}\text { Course pages have links that are self- } \\
\text { describing and meaningful. }\end{array}$ & $\begin{array}{l}\text { Very impor- } \\
\text { tant }\end{array}$ & 2 & $\begin{array}{l}2 \text { - links are labeled so they } \\
\text { are easily identifiable; the } \\
\text { same applies to files. }\end{array}$ \\
\hline 8.4 & The course ensures screen readability. & Important & 1 & $\begin{array}{l}1 \text { - information is presented } \\
\text { primarily in text format so } \\
\text { as to be readable easily by } \\
\text { screen reader software }\end{array}$ \\
\hline
\end{tabular}

The course faired well with respect to standards concerning course review and introduction, course technology, learner support, and accessibility (dimensions 1, 6, 7 and 8 in the QM Rubric). However, the self-evaluation instrument identified significant areas for improvement, in particular in the area of module/unit learning objectives, assessment, and alignment of instructional materials and activities with the stated learning objectives (L.Os).

The second author was somewhat surprised with these outcomes. She was used to relying on L.Os listed on each chapter of the textbook and perceived that students knew how different assignments and instructional materials helped them achieve the L.Os. In order to meet the QM standards where the course design fell short, the following changes were implemented:

\section{Module/unit L.Os:}

The authors organized the course into seven modules or units and designed L.Os for each unit. Because of the nature of this accounting course, each unit built on learning achieved in the previous units, culminating with a unit on relevant costs that summarized and expanded on concepts from all other units in the course. 


\section{Map Linking Course L.Os, Unit L.Os, Course Materials and Assessment Instruments}

The second author developed a matrix linking course and unit L.Os to course materials and assessment instruments such as quizzes, exams and cases. An excerpt of parts of this matrix is shown in Table 2.

\begin{tabular}{|c|c|c|c|c|c|c|c|}
\hline \multicolumn{8}{|c|}{ Table 2: Excerpts from the L.Os. matrix } \\
\hline L.O.\# & $\begin{array}{c}\text { COURSE } \\
\text { L.O. }\end{array}$ & UNIT L.O. & $\begin{array}{l}\text { READ- } \\
\text { INGS }\end{array}$ & $\begin{array}{l}\text { PRACTICE } \\
\text { PROBLEMS }\end{array}$ & QUIZ & EXAMS & CASES \\
\hline 2 & $\begin{array}{l}\text { Illustrate } \\
\text { advantages } \\
\text { and limita- } \\
\text { tions of cost } \\
\text { management } \\
\text { tools }\end{array}$ & $\begin{array}{l}\text { Illustrate ad- } \\
\text { vantages of } \\
\text { differential, } \\
\text { sunk and op- } \\
\text { portunity } \\
\text { costs }\end{array}$ & chap. 13 & $\begin{array}{l}13-7,12,13 \text { and } \\
18\end{array}$ & 7 & Final & $\begin{array}{l}\text { Prestige } \\
\text { Tele- } \\
\text { phone } \\
\text { Company }\end{array}$ \\
\hline 6 & $\begin{array}{l}\text { Evaluate tra- } \\
\text { ditional and } \\
\text { activity- } \\
\text { based costing }\end{array}$ & $\begin{array}{l}\text { Explain ad- } \\
\text { vantages of } \\
\text { traditional and } \\
\text { ABC costing } \\
\text { methods. }\end{array}$ & $\begin{array}{l}\text { chaps. } 3 \\
\text { and } 8\end{array}$ & $\begin{array}{l}3-15,20 \text { and } 25 \\
8-3,4 \text { and } 14\end{array}$ & 2 and 3 & Midterm & $\begin{array}{r}\text { Survey } \\
\text { Masters } \\
\text { Company }\end{array}$ \\
\hline
\end{tabular}

The matrix was posted on the course website and the instructor referred to it periodically throughout the course. The matrix helped balance out the selection of course materials and assessment instruments for different L.Os, so that every unit L.O. was assessed by at least one instrument, and course materials were available for every L.O. In future revisions of the course, the matrix provides a visual aid to help select new course materials and write new assessment instruments: if a case, for example, was linked to L.Os 2, 37 and 11, a replacement case should also address at least some of those L.Os, or another combination of cases will need to be selected. Students benefited from the matrix because it made apparent to them that each course material and assessment instrument had a purpose and helped the achievement of certain L.Os.

\section{Requirements for Student Interaction and Grading Policy}

Expectations for student interaction and the grading criteria were briefly discussed in the syllabus but a significant number of student emails asked for clarifications such as, "how many times do I need to participate in the discussion area to get an A?" or "how do you grade the weekly quizzes and how many points would I lose if I missed one quiz?" were typical questions. The authors had previously assumed that after the first couple of weeks the students would figure out how the grading policy worked in practice. But better still would be to have students be clear, from the very first day the course opens online, about what is expected from them and how their assignments will be graded.

The authors developed a rubric for participation in the case discussions (see Table 3) and posted it in the course website. In the syllabus, hypothetical examples were included to show how the weight placed on quizzes affected the overall course grade. These changes alone cut down significantly the number of emails asking for clarification and led to better student-to-student interactions. 
Table 3: A rubric for participating in case discussions

\begin{tabular}{|c|c|c|}
\hline ZERO POINTS & ONE POINT & TWO POINTS \\
\hline \multicolumn{3}{|c|}{ Situation 1: If you are a member of the group responsible for a case: } \\
\hline $\begin{array}{l}\text { The group did not respond to } \\
\text { questions from the class, nor did } \\
\text { the group post any questions to } \\
\text { stimulate discussion. }\end{array}$ & $\begin{array}{l}\text { The group responded to questions } \\
\text { from the class, but not all and not } \\
\text { in a timely and comprehensive } \\
\text { fashion. }\end{array}$ & $\begin{array}{l}\text { The group responded to all ques- } \\
\text { tions from the class, in a timely } \\
\text { fashion; the group posted new } \\
\text { questions to stimulate discussion }\end{array}$ \\
\hline \multicolumn{3}{|c|}{ Situation 2: If you are not a member of the group responsible for a case: } \\
\hline $\begin{array}{l}\text { You did not post anything or your } \\
\text { posting did not demonstrate know- } \\
\text { ledge of the case content. }\end{array}$ & $\begin{array}{l}\text { You posted comments one or two } \\
\text { times during the week, revealing } \\
\text { that you read the case and the } \\
\text { group's posting. }\end{array}$ & $\begin{array}{l}\text { You posted three times during the } \\
\text { week, revealing that you read the } \\
\text { case and the group's solution, and } \\
\text { that you added some original } \\
\text { thought to the case analysis. }\end{array}$ \\
\hline $\begin{array}{l}\text { examples: "I agree with Joe." or } \\
\text { "Great job, group 3!" }\end{array}$ & $\begin{array}{l}\text { "The main cause for the World- } \\
\text { Com fraud was the terrible corpo- } \\
\text { rate culture. I disagree with the } \\
\text { group that said the main cause was } \\
\text { the lack of consistent accounting } \\
\text { policies among the subsidiaries." }\end{array}$ & $\begin{array}{l}\text { "The main cause for the World- } \\
\text { Com fraud was the terrible corpo- } \\
\text { rate culture. I disagree with the } \\
\text { group that said the main cause was } \\
\text { the lack of consistent accounting } \\
\text { policies among the subsidiaries. I } \\
\text { have worked in a large bank where } \\
\text { managers felt the pressure from } \\
\text { the top to manipulate earnings. " }\end{array}$ \\
\hline
\end{tabular}

In addition, the second author posted a list of items under the title "to get started in this course" right on the class announcements page, so that it would be easily found by the students at the time of the first login. The list included "to do" activities for the first week, such as "read chapters 1 and 2 of the textbook," "join a study group and select a case," etc. Even though this information was already evident from the description of assignments on the syllabus, the redundancy of having these instructions also in the class announcements page reduced considerably the number of student emails asking for clarification, especially from students joining the course late in the second week.

\section{Accessibility}

The second author recorded videos of 20-minute lectures to illustrate the hardest chapters on the textbook and posted those for student use in the course website. The powerpoint slides used during these lectures were also posted for student use in the course website. However, one hearingimpaired student asked to have the audio portion of these lectures transcribed in a document that he could easily access. Although the lectures were not a required instructional material, the student felt he did not want to lose the opportunity of fully using all the resources available on the course site. The second author transcribed the lectures into Microsoft Word files and posted those files on the course website. The experience with this hearing-disabled student prompted the university to obtain professional transcribing services for other disabled students. This is consistent with standard 8.2 in the QM Rubric: each material posted on the course website should have alternatives to auditory and visual content. 


\section{Conclusion}

This paper addressed the use of the Quality Matters Rubric for quality assurance in online courses. Drawing from the experience of preparing a graduate accounting course for QM certification, the paper describes the self-assessment process and the course design changes implemented as a result of the self-assessment. It contributes to the growing literature on quality assurance in distance education settings, by illustrating the use of a rubric that is quickly becoming the industry standard, and by discussing the practical implications of implementing changes in course design to achieve quality certification.

From the instructor's viewpoint, the main benefits from QM implementation consisted of a clearer alignment of course and unit learning objectives with assessment instruments and instructional materials. This alignment facilitated planning of which materials and instruments to use, where to place them in the course schedule, and how to replace course materials and assessment instruments for future course revisions.

From the students' viewpoint, the main benefits from QM implementation consisted of an explicit set of instructor's expectations and a clearly stated grading policy. For example, instead of trying to figure out what the instructor expected from case discussions after the first couple of weeks into the course, students were able to manage their time better and achieve the L.Os sooner.

Even though the course described in this study is still in the early stages of the continuous improvement process triggered by the QM review, some measurable results have become evident. Student evaluations of the course, which averaged 3.5 (in a 5-point scale where 5 represents outstanding) have risen to an average of 4.3 in the two semesters following the self-assessment for QM review. Similarly, the class Grade Point Average increased from 3.08 to 3.78.

Another advantage of the QM review process is that it provides a clear set of guidelines for regular faculty members who are charged with the task of new course development. While some large universities can boast the availability of a full cadre of instructional designers for course development, other universities simply have to rely on their regular faculty, many times with limited pedagogical training, to design a course from scratch. With the help of the QM Rubric, faculty can rely on research-based standards to design new online courses and continuously improve on the course to help students achieve the learning objectives.

While the Quality Matters Rubric has been time-tested over the past six years and enlisted 372 institutional subscribers in 42 states in the US, Canada and the Bermuda, it will have to continuously adapt to new learners and programs in order to remain effective. Future studies could devote more attention to how quality standards in online education will evolve to respond to the preferences in learning styles of new generations of students, and to reap the full benefits of new technologies to come.

\section{References}

AACSB. (2009). Eligibility procedures and standards for business accreditation. Retrieved December 7, 2009, from http://www.aacsb.edu/accreditation/standards.asp

Achtemeier, S. D., Morris, L. V., \& Finnegan, C. L. (2003 February). Considerations for developing evaluations of online courses. Journal of Asynchronous Learning Network, 7(1). Retrieved December 7, 2009, from http://www.aln.org/publications/jaln/v7n1/pdf/v7n1_achtemeier.pdf

Bloom B. (Ed.) (1956). Taxonomy of educational objectives: The classification of educational goals. Handbook 1: Cognitive Domain. New York: McKay

Chaney, B. H. (2006). History, theory, and quality indicators of distance education: A literature review. College Station, Texas: Texas A \& M University, Office of Health Informatics. Retrieved December 7, 2009, from http://ohi.tamu.edu/distanceed.pdf 
Chaney, B. H., Eddy, J. M., Dorman, S. M., Glessner, L., Green. B. L., \& Lara-Alecio, R. (2007). Development of an instrument to assess student opinions of the quality of distance education courses. The American Journal of Distance education, 21(3), 145-164.

Garrison, D. R., Anderson, T., \& Archer, W. (2001). Critical thinking, cognitive presence, and computer conferencing in distance education. American Journal of Distance Education, 15(1), 7-23.

Kinash, S., Crichton, S., \& Kim-Rupnow, W. S. (2004). A review of 2000-2003 literature at the intersection of online learning and disability. The American Journal of Distance Education, 18(1), 5-19.

Koszalka, T. A. \& Ganesan, R. (2004). Designing online courses: A taxonomy to guide strategic use of features available in course management systems (CMS) in distance education. Distance Education, 25(2), 243-256.

Moore, M. G. (2007). Web 2.0: Does it really matter? The American Journal of Distance Education, 21(4), 177-183.

National Center for Education Statistics. (2008). Distance education at degree-granting postsecondary institutions: 2006-07. Retrieved December 7, 2009, from http://nces.ed.gov/pubs2009/2009044.pdf

Roblyer, M. D., \& Wiencke, W. R. (2003). Design and use of a rubric to assess and encourage interactive qualities in distance courses. The American Journal of Distance Education, 17(2), 77-98.

Rourke, L., Anderson, T., Garrison, D. R., \& Archer, W. (2001). Assessing social presence in asynchronous text-based computer conferencing. Journal of Distance Education, 14(2), 50-71. Retrieved December 7, 2009 from http://cade.athabascau.ca/voll4.2/rourke et al.html

Stewart, I., Hong, E., \& Strudler, N. (2004). Development and validation of an instrument for student evaluation of the quality of web-based instruction. The American Journal of Distance Education, 18(3), 131-150.

Swan, K., (2003). Learning effectiveness: What the research tells us. In J. Bourne \& J. Moore (Eds.), Elements of quality online education: Practice and direction (pp.13-46). Needham, MA: Sloan-C.

Thurmond, V., Wambach, K., Connors, H., \& Frey, B. (2002). Evaluation of student satisfaction: Determining the impact of a web-based environment by controlling for student characteristics. The American Journal of Distance Education, 16(3), 169-89.

Welker, J. \& Berardino, L. (2005). Blended learning: Understanding the middle ground between traditional classroom and fully online instruction. Journal of Educational Technology Systems, 34(1), 33-55.

Youngblood, P., Trede, F., \& DeCorpo, S. (2001). Facilitating online learning: A descriptive study. Distance Education, 22(2), 264-284.

\section{Biographies}

Dr. Regina F. Bento is a Professor of Management at the Merrick School of Business, at the University of Baltimore. Trained in Brazil as a psychiatrist and with a doctorate in management from the Massachusetts Institute of Technology, her research examines the nature of work and organizations. She has received numerous awards, including the USM Regents Award, the highest honor in the University System of Maryland. She is one of the pioneers in online education in the United States, and has written extensively about pedagogical issues and innovations in distance learning. Dr. Bento has served in elected leadership positions in several academic organizations, such as the Management Education and Development Division of the Academy of Management, and has recently served a three-year term as Associate Director of the C. Roland Christensen Center for Learning and Teaching at the Harvard Business School, where she helped train Harvard faculty on how to teach using the case method. Dr. Bento holds associate editor or editorial board positions in journals such as the Academy of Management Learning and Education and Sex Roles: A Journal of Research. Her publications include an award-winning book; chapters in 
books published by the Harvard Business School Press, Sage, Jossey Bass and others; articles in journals such as Human Resource Management Journal, Information and Management, Communications of the AIS, Journal of Management Education, Journal of Managerial Psychology, and others.

Dr. Lourdes F. White is the Ernst \& Young Professor of Accounting at the Merrick School of Business, University of Baltimore. A graduate from Harvard, her areas of research include budgeting, performance management, and incentive compensation. She has published in Accounting, Auditing and Accountability Journal, Advances in Accounting Education, Advances in Management Accounting, Human Resource Management Journal, Journal of Accounting Education, Journal of Corporate Finance, Research in Governmental and Nonprofit Accounting, and others. 